\title{
PHARMACOKINETICS OF BROTIZOLAM IN RENAL FAILURE
}

\section{J. EVERS \& E. RENNER}

Med. Klinik I, Köln-Merheim

W.D. BECHTEL

Department of Biochemistry, Boehringer Ingelheim KG, Federal Republic of Germany

1 Kinetics of brotizolam $(0.25 \mathrm{mg})$ were studied in patients with different degrees of renal failure after single and repeated oral ingestion. Serum levels were analysed by radio-immunoassay.

2 Patients were divided into three groups according to their renal function, i.e. creatinine clearance values of $45-80,15-45$, or less than $15 \mathrm{ml} / \mathrm{min}$.

3 The mean elimination half-life was $6.9-8.15 \mathrm{~h}$, with a considerable variation of the peak concentration and elimination half-life in slight to moderate renal failure. There was no delay in elimination in severe renal failure and there was no drug accumulation.

4 No dose adjustment is necessary for brotizolam in renal failure.

Keywords brotizolam pharmacokinetics renal failure

\section{Introduction}

Drug action is often modified in patients with renal failure by alterations of absorption, protein-binding, distribution and metabolism, diminished excretion and retention of active metabolites (Anon, 1977).

Benzodiazepines are metabolized mainly in the liver and metabolites are excreted by the kidney, but there is considerable variability between individual compounds in rates of metabolism and excretion (Bennett, 1980). Whereas diazepam can be used without dose adjustment in renal failure, flurazepam should be used with caution.

Up to $65 \%$ brotizolam (1\% of it unchanged) is excreted by the kidney (Bechtel, 1983) and information on elimination in renal failure is therefore of importance. The purpose of this study was to determine the handling of brotizolam after single and repeated oral dosage in patients with different degrees of renal insufficiency.

\section{Methods}

Eighteen patients were selected from amongst a group of in-patients and divided into three categories: those with mild renal insufficiency (creatinine clearance $45-100 \mathrm{ml} / \mathrm{min}$ ), those with moderate renal insufficiency (creatinine clearance $15-45 \mathrm{ml} / \mathrm{min}$ ) and severe renal insufficiency (creatinine clearance less than $15 \mathrm{ml} / \mathrm{min}$ ). The patients were aged between 21 and 63 years, the average being 51 years. Patients with impaired hepatic function were excluded. The patients' personal data are listed in Table 1 and their underlying diseases and concomitant therapy in Table 2.

All patients were informed about the nature of the investigation and each received one $0.25 \mathrm{mg}$ brotizolam tablet with $100 \mathrm{ml}$ water on the first and seventh days at $08.00 \mathrm{~h}$ and from the first to the sixth days at $21.00 \mathrm{~h}$. The patients fasted overnight on the first and last trial days and received breakfast $1 \mathrm{~h}$ after taking the morning tablet. Blood $(5 \mathrm{ml})$ was collected from each patient shortly before and at 2, 4, 6, 8 and $10 \mathrm{~h}$ after taking the tablet. These samples were centrifuged and stored at $-20^{\circ} \mathrm{C}$ until they could be analysed.

The quantitative assay of brotizolam in the serum was performed using a radioimmunoassay specific for brotizolam (Bechtel, 1983).

\section{Results}

Figure 1 shows graphically the mean values of the serum levels of the three groups for the first and seventh days of the study. The serum levels reached their maximum relatively rapidly (after approxi- 
Table 1 Patient data

\begin{tabular}{ccccccc}
\hline Patient & Sex & $\begin{array}{c}\text { Age } \\
\text { (years) }\end{array}$ & $\begin{array}{c}\text { Height } \\
(\mathrm{cm})\end{array}$ & $\begin{array}{c}\text { Weight } \\
(\mathbf{k g})\end{array}$ & $\begin{array}{c}\text { Serum } \\
\text { creatinine } \\
(\text { mg \%) }\end{array}$ & $\begin{array}{c}\text { Creatinine } \\
\text { clearance } \\
(\text { ml/min })\end{array}$ \\
1 & F & 40 & 150 & 59 & 2.0 & 60 \\
2 & M & 58 & 164 & 75 & 1.6 & 70 \\
3 & M & 59 & 172 & 76 & 1.8 & 60 \\
4 & F & 54 & 152 & 73 & 1.7 & 60 \\
5 & M & 56 & 178 & 75 & 1.5 & 80 \\
6 & M & 49 & 176 & 76 & 1.3 & 80 \\
7 & M & 55 & 172 & 81 & 6.0 & 15 \\
8 & M & 37 & 178 & 88 & 2.6 & 40 \\
9 & F & 60 & 162 & 83 & 2.7 & 31 \\
10 & M & 59 & 178 & 70 & 3.0 & 25 \\
11 & F & 63 & 154 & 70 & 2.5 & 25 \\
12 & F & 21 & 160 & 54 & 2.7 & 30 \\
13 & F & 60 & 166 & 61 & 10.0 & $<10$ \\
14 & M & 45 & 176 & 67 & 10.0 & $<10$ \\
15 & M & 54 & 178 & 76 & 7.0 & $<15$ \\
16 & F & 44 & 161 & 69 & 10.0 & $<10$ \\
17 & M & 52 & 168 & 73 & 9.0 & $<10$ \\
18 & M & 51 & 164 & 61 & 10.0 & $<10$
\end{tabular}

Table 2 Patient data

\begin{tabular}{|c|c|c|}
\hline Patient & Diagnosis & Therapy \\
\hline 1 & Chronic pyelonephritis & - \\
\hline 2 & Nephrosclerosis & Isosorbide, phenprocoumon \\
\hline 3 & Toxic nephropathy & Mezlocillin, digoxin, pirenzepine \\
\hline 4 & Glomerulonephritis & Amiloride, hydrochlorothiazide \\
\hline 5 . & Nephrosclerosis & $\begin{array}{l}\text { Allopurinol, atenolol, acetylsalicylic acid, molsidomine, frusemide, } \\
\text { penicillamine }\end{array}$ \\
\hline 6 & Renal artery stenosis & Propranolol, hydralazine, clonidine, triamterene, thiazide \\
\hline 7 & Chronic interstitial nephritis & Ampicillin \\
\hline 8 & Glomerulonephritis & Dihydroergocristine, clopamide, reserpine, allopurinol \\
\hline 9 & Plasmacytoma kidney & Cyclophosphamide, digoxin, doxycycline, L-thyroxine \\
\hline 10 & Glomerulonephritis & $\begin{array}{l}\text { Captopril, propranolol, acetylsalicylic acid, dipyridamole, hydralazine, } \\
\text { trusemide, allopurinol, digoxin }\end{array}$ \\
\hline 11 & Renal cysts, pyelonephritis & Heparin, digoxin \\
\hline 12 & Kidney transplantation & Azathioprine, fluocortolone, frusemide, gelusil, nystatin \\
\hline 13 & Polycystic disease & Frusemide, clemastine \\
\hline 14 & Pyelonephritis, paraplegia & - \\
\hline 15 & Polycystic disease & Hydralazine, atenolol, metoclopramide \\
\hline 16 & $\begin{array}{l}\text { Chronic renal failure } \\
\text { (unknown aetiology) }\end{array}$ & Hydralazine, atenolol, frusemide, aluminium hydroxide \\
\hline 17 & Glomerulonephritis & $\begin{array}{l}\text { Prazosin, metoprolol, clonidine, frusemide, nitroglycerin, allopurinol, } \\
\text { hydralazine, captopril }\end{array}$ \\
\hline 18 & Glomerulonephritis & Digoxin, pindolol, calcium, dipyridamole \\
\hline
\end{tabular}




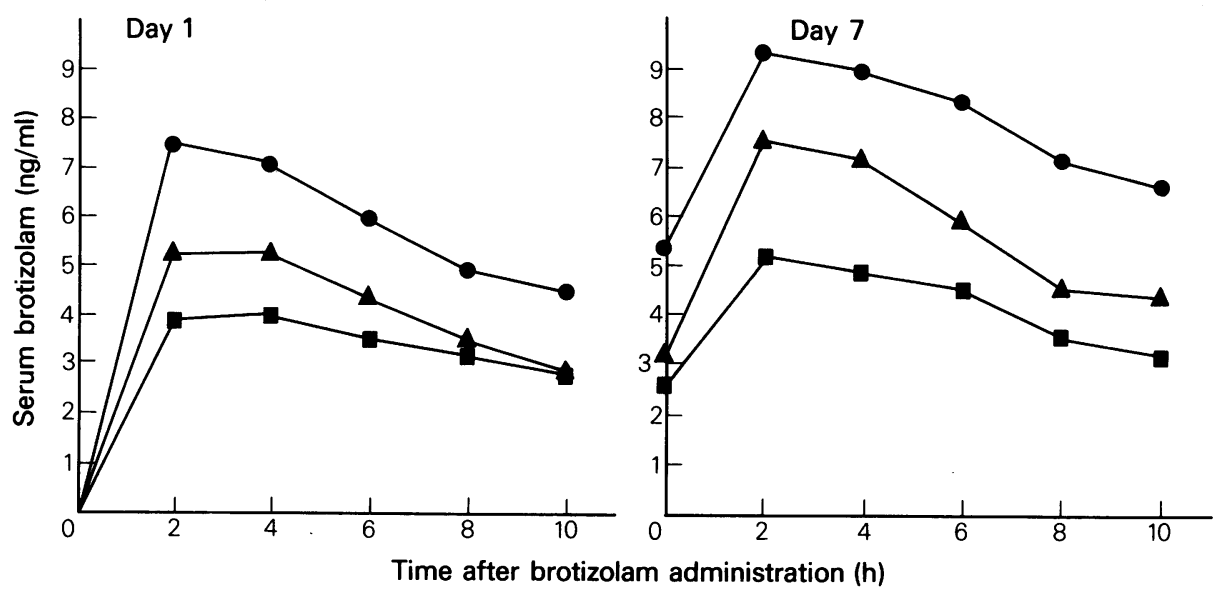

Figure 1 Serum levels of brotizolam on days 1 and 7 of the trial in patients $1-6(0$, with renal insufficiency), patients 7-12 ( $\square$, moderate renal insufficiency) and patients $13-18(\Delta$, severe renal insufficiency).

mately $2 \mathrm{~h})$. The elimination half-life $\left(t_{1 / 2, \mathrm{z}}\right)$ was calculated from the serum levels of each patient and ascertained for each group separately. These results are shown in Table 3.

There was a wide range of maximum serum levels and elimination half-lives in patients with mild and moderate renal insufficiency. Isolated extreme values (half-lives of 17.08 and $60.32 \mathrm{~h}$ ) affected greatly the overall picture. In the patients with severe renal insufficiency, on the other hand, consistent results were found, with an elimination half-life of $6.9 \mathrm{~h}$ on the first and $7.61 \mathrm{~h}$ on the last trial day.

There was no clinical evidence of cumulation of brotizolam. No increased tiredness was observed throughout the trial and laboratory parameters and vital functions (blood pressure, pulse rate, temperature, diuresis, bowel movement and appetite) remained unchanged.

\section{Discussion}

A wide range of maximum serum concentrations and elimination half-lives for diazepines has been demonstrated (Breimer \& Jochemsen 1983). Nevertheless, it was necessary to exclude the more extreme values obtained for some patients in this study-those for patient number 8 because they appear to be caused by

Table 3 Elimination of brotizolam from the serum of patients suffering from renal insufficiency after administration of one $0.25 \mathrm{mg}$ tablet

\begin{tabular}{crrrr}
\hline Patient & $\mathrm{t}_{1 / 2, \mathrm{z}}(\boldsymbol{h})$ & $\begin{array}{c}\text { Day } 1 \\
\text { Mean } \pm \text { s.d. }(h)\end{array}$ & $\mathrm{t}_{1 / 2, \mathrm{z}}(\boldsymbol{h})$ & $\begin{array}{c}\text { Day } 7 \\
\text { Mean } \pm \text { s.d. }(h)\end{array}$ \\
1 & & & 6.81 & \\
2 & 4.05 & & 10.57 & \\
3 & 11.08 & & 8.90 & \\
4 & 5.46 & & 25.25 & \\
5 & 6.70 & & 6.33 & \\
6 & 8.88 & & - & $11.57 \pm 7.83$ \\
7 & 17.08 & $8.88 \pm 4.73$ & 6.65 & \\
8 & 6.70 & & 20.66 & \\
9 & 60.63 & & 8.87 & \\
10 & 7.11 & & 7.66 & \\
11 & 26.28 & & 3.04 & \\
12 & - & & 9.03 & $8.99 \pm 6.06$ \\
13 & 9.02 & $21.95 \pm 23.10$ & 6.81 & \\
14 & 6.49 & & 8.18 & \\
15 & 3.77 & & 8.14 & \\
16 & 11.45 & & 7.73 & \\
17 & 6.78 & & 6.61 & \\
18 & 8.95 & & & \\
& 3.96 & $6.90 \pm 2.95$ & 8.18 & \\
& & & &
\end{tabular}




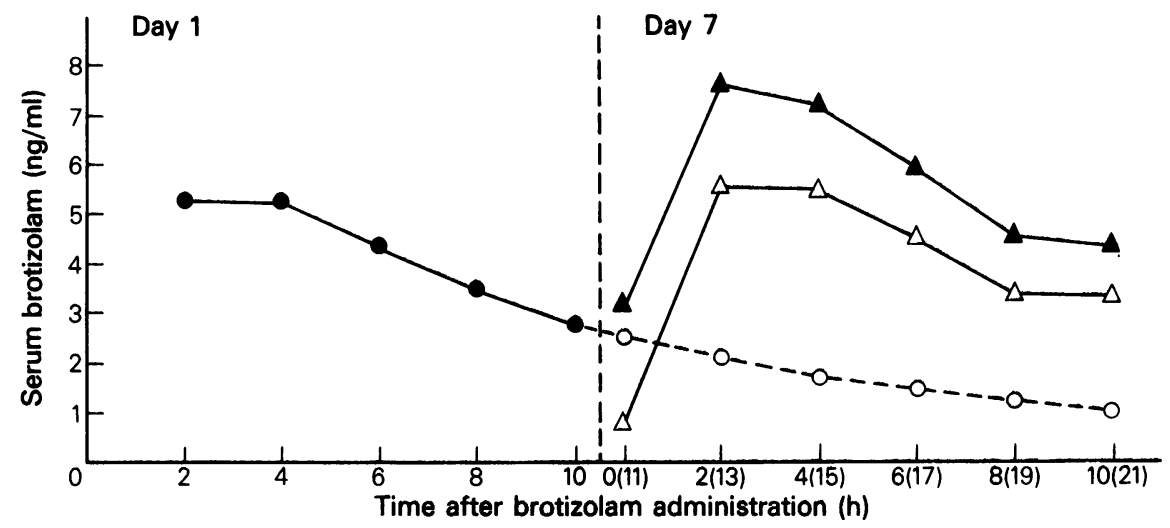

Figure 2 Serum levels of brotizolam on day $1(\Theta)$ and day $7(\Delta)$ of the trial in patients with severe renal insufficiency. $\Delta$ serum levels corrected by the residual value, which was taken from the extrapolated serum levels (O).

artefact, and those for patients numbers 4,6 and 10 because there was no correlation between figures obtained on the first and seventh days. There was no apparent relationship between the values obtained and age, weight, underlying disease, concomitant medication or previous administration of diazepines. Even in those patients who were excluded from the overall analysis, no evidence of accumulation of brotizolam was obtained on the seventh day.

The widest range of results occurred in those patients with mild and moderate renal insufficiency, while the values for patients with severe renal insufficiency were clustered together within this range. The consistent pattern of serum concentrations obtained for the patients with severe renal insufficiency indicate clearly, in contrast to the results for the other groups, that there was no delay in elimination or accumulation of brotizolam after repeated administration.

The serum levels recorded on the seventh day were higher than those on the first day; this was caused by the evening administration of brotizolam $11 \mathrm{~h}$ previously. If the values obtained for the seventh day are corrected by the residual value, which can be cal-

\section{References}

ANON (1977). Symposium on drug action and metabolism in renal failure. Am. J. Med., 62, 459-563.

BENNETT, W.M. (1980). Drug therapy in renal failure. Ann. Int. Med., 93, 286-325.

BECHTEL, W.D. (1983). Pharmacokinetics and metabolism
Table 4 Mean elimination half-lives (excluding the patients with extreme values)

\begin{tabular}{llcc}
\hline Patient & $\begin{array}{c}\text { Degree of } \\
\text { insufficiency }\end{array}$ & $\begin{array}{c}\text { Day } 1 \\
\mathrm{t}_{1 / 2, \mathrm{z}}(\boldsymbol{h})\end{array}$ & $\begin{array}{c}\text { Day } 7 \\
\mathrm{t}_{1 / 2, \mathrm{z}}(\boldsymbol{h})\end{array}$ \\
$1-3,5$ & Mild & 7.37 & 8.15 \\
$7,9,11,12$ & Moderate & 7.61 & 6.90 \\
$13-18$ & Severe & 6.90 & 7.61
\end{tabular}

culated from the half-life, for the previous dose, the curves for the first and seventh days are the same (Figure 2).

If the extreme values obtained for patients $4,6,8$ and 10 are excluded, the serum half-life is between 6.90 and $8.15 \mathrm{~h}$ (Table 4), which falls within the range which was found in a recent study on 24 volunteers with normal renal function, i.e. an average of 7.1 to $7.9 \mathrm{~h}$ (Bechtel, 1983).

In summary, there is no prolongation of serum half-life and no accumulation of brotizolam in renal insufficiency, and there is therefore no need to adjust the dose, at least during short-term therapy.

of brotizolam in humans. Br. J. clin. Pharmac., 16, 279S-283S.

BREIMER, D.D. \& JOCHEMSEN, R. (1983). Clinical pharmacology of hypnotic benzodiazepines: a summary. $\mathrm{Br}$. J. clin. Pharmac., 16, 277S-278S. 
Pharmakokinetik von Brotizolam bei Niereninsuffizienz

J. Evers, E. Renner \& W.D. Bechtel

1 Die Kinetik von Brotizolam $(0,25 \mathrm{mg})$ wurde bei Patienten mit verschiedenen Schweregraden einer Niereninsuffizienz nach einmaliger und wiederholter oraler Einnahme untersucht. Die, Serumspiegel wurden mittels Radioimmunoassay bestimmt.

2 Die Patienten wurden in drei Gruppen je nach ihrer Nierenfunktion aufgeteilt, d.h. KreatininClearancewerte von $45-80,15-45$ oder geringer als 15 $\mathrm{ml} / \mathrm{min}$.

Pharmacocinétiques du brotizolam dans l'insuffisance rénale

J. Evers, E. RenNer \& W.D. Bechtel

1 La cinétique du brotizolam $(0.25 \mathrm{mg})$, administré par voie orale en dose unique ou répétée, a été étudiée chez des patients présentant divers degrés d'insuffisance rénale. Les taux sériques ont été analysés par la méthode radio-immunologique.

2 Les patients ont été divisés en trois groupes en fonction de l'état de leur fonction rénale, c'est-à-dire des taux de clairance de la créatinine de $45-80,15-45$ et moins de $15 \mathrm{ml} / \mathrm{min}$.

\section{Farmacocinética de brotizolam en la insuficiencia renal}

J. Evers, E. ReNNER \& W.D. Bechtel

1 Se estudió la cinética de brotizolam $(0,25 \mathrm{mg})$ en pacientes con diverso grado de insuficiencia renal tras ingestión única y repetida. Los niveles en suero se analizaron mediante radio-inmunoensayo.

2 Los pacientes fueron distribuídos en 3 grupos según su función renal, es decir, con valores de depuración de creatinina de 45-80, 15-45 o menos des $15 \mathrm{ml} / \mathrm{min}$.
3 Die mittlere Eliminationshalbwertzeit betrug 6,9-8,15 Stunden bei erheblicher Schwankung der Spitzenwerte und Eliminationshalbwertzeiten bei leichter bis mittelschwerer Niereninsuffizienz. Es fand sich keine Ausscheidungsverzögerung bei schwerer Niereninsuffizienz und auch keine Kumulation des Arzneimittels.

4 Eine Dosisanpassung bei Niereninsuffizienz ist für Brotizolam nicht erforderliuch.

3 La demi-vie moyenne d'élimination a été de $6,9-8,15 \mathrm{~h}$, les pics de concentration et la demi-vie d'élimination ayant présenté des variations considérables dans les insuffisances rénales légères à moyennes. Il n'y a pas eu de retard d'élimination dans l'insuffisance rénale grave ni non plus d'accumulation de la substance.

4 Il n'est pas nécessaire d'ajuster la dose de brotizolam dans l'insuffisance rénale.

3 La vida media de eliminación promedio fue de $6,9-8,15 \mathrm{~h}$, con variación considerable de la concentración máxima y de la vida media de eliminación en los casos de insuficiencia renal level a moderada. No hubo retardo de la eliminación en!la insuficiencia renal grave y no existió tampoco acumulación del fármaco. 4 No se requiere una adaptación de la dosis de brotizolam en la insuficiencia renal. 